\title{
Factors Influencing Worker Motivation in a Private African University: Lessons for Leadership
}

\author{
Anthony Afful-Broni ${ }^{1}$, Stephen Nanyele ${ }^{2}$ \\ ${ }^{1}$ University of Education, Winneba, Ghana \\ ${ }^{2}$ Catholic University College of Ghana, Fiapre, Ghana \\ Email: aabroni50@gmail.com
}

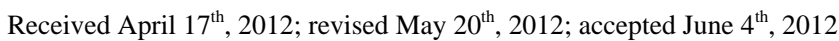

\begin{abstract}
Maintaining high performing employees and keeping them in line with organizational goals have been identified as major challenges facing employers and managers of organizations. An important factor influencing worker commitment and productivity is motivation. This study was carried out to assess factors influencing motivation of workers in the Catholic University College of Ghana, Fiapre, and to draw lessons for administrators and staff in agrarian communities. Structured and semi-structured questionnaires were administered to 80 respondents selected from a staff population of 116 . The study discovered that love for the job, career development prospects, good salary and healthy relations were largely responsible for the motivation of workers. The study also revealed that there are certain hidden incentives in the district which served as motivation to the workers; notable among them are low cost of foodstuff, cheaper transportation and housing. The study recommends that leaders should help create more factors which will attract workers to go to agrarian communities, rather than scrambling for places in the overcrowded cities of Ghana.
\end{abstract}

Keywords: Worker Motivation; Staff Output in Private University

\section{Introduction}

There is consensus among management practitioners and scholars that human beings occupy a very important place in every successful organization. Thaw (2002) has pointed out that without people there is no organization. Having identified three main elements of every organization as people, structure and purpose, Thaw (2002) believes that all these elements are needed for an organization to exist and function successfully. Other scholars of management have further argued in support of this assertion that people are the most essential and valued assets of an organization. It is the people's efforts which contribute to the achievement of any organization's objectives (Armstrong, 2001). Cole (2002) affirms this in his conviction that arguably, the most essential single resource in any organization is people.

Hiring and retaining highly skilled and motivated labour has been found to improve efficiency and increase productivity in every organization. Maintaining high performing employees and keeping them in tune with organizational goals have been identified as the main challenge facing many employers and managers of organizations. Managers who attempt to impose formal or strict standards and procedures on their workers in order to maintain productivity end up inviting resistance or hostile reactions and in some cases, risk incurring personnel turnovers. However, all over the globe, employers and managers have found it increasingly difficult to hire and maintain the desired calibre of staff (Miskell \& Miskell, 1999). Yet, simply hiring the best people with extraordinary competence, expertise and abilities does not necessarily guarantee high productivity. A lot also depends on the determinants of motivation (Valogo, 2007).

Robbins \& Laughton (2001) define motivation as a process that accounts for an individual's intensity, direction and persistence of efforts towards achieving a goal. This suggests that whether or not an employee chooses to work hard towards the attainment of set goals of the organization at any given point depends to a large extent on certain factors which are driving him/her to do so. It is these determinant factors that every manager or leader needs to identify in each individual in order to sustain his/her efforts at work. Money in this sense is therefore, one of the fundamental factors in any employer-employee relationship. Doyle (1992) has also observed that money as a medium of exchange is the means by which employees can obtain their numerous needs to satisfy their desire. For Doyle (1992), money is also the "score card by which employees assess the value that the organization places on their services and by which employees can compare their values to others" (p. 641).

According to the Needs Theory, money is an immediate and powerful tool of motivation as far as the satisfaction of basic human needs is concerned. For example, considering Maslow's needs theory, money is likely to be a motivator to people who are still grappling with physiological needs and safety or security needs. People who are striving for higher order needs such as esteem and self-actualization, according to Maslow, are less concerned about money in the work. According to Alderfer's Existence Relatedness and Growth theory, (Afful-Broni, 2004) people will be motivated by money when they have a strong need for existential or survival needs which correspond to Maslow's physiological and safety needs.

Another study carried out by Locke and cited in Robbins and Laughton (2001) at the University of Maryland compared four (4) main methods of motivating workers' performance, namely, money, goal setting, participation in decision making and re- 
designing jobs to give workers more challenge and responsibility. The results found in terms of average improvement in performance were as follows; $30 \%$ for money, $10 \%$ for goal setting, less than $1 \%$ for participation in decision making and $17 \%$ for job redesign improved performance. Locke's research revealed that though money is an important factor and certainly a very strong motivator of employee performance, not everyone is primarily or fundamentally motivated by money.

The findings of Locke's research cannot be used to draw a general conclusion on factors motivating workers everywhere in the world and in every organization. In a research in Ghana for example, Sefa (2007) explored the effect of motivation on productivity in three business organizations, namely, Peace FM, Pipes and Plastics and Poly Products, all in the capital city of Accra. Sefa (2007) found that the employees of these organizations generally felt demotivated to work hard. The greater number of the workers (90\%) was however motivated by monetary reward rather than promotions, status and recognition.

In this study we sought to determine the factors of motivation at the Catholic University College of Ghana (CUCG) at Fiapre. Specifically, the study aimed at finding out the factors that motivate workers at the CUCG, determine the extent to which CUCG workers are satisfied with the motivational packages put in place by the University and also draw lessons for administrators and managers as well as staff motivation in agrarian settings for this and other institutions with similar characters. Thus, the examination of the factors motivating staff at CUCG in Fiapre is significant in several ways. The study will showcase the strengths and weaknesses of the strategies adopted by the University in meeting the motivational needs of staff; as it is believed that this can bring about further improvement in staff attraction and retention rate.

The possible improvement in the motivational packages will be of direct benefit to the management and staff of the University in their quality of life. It is contended that the study is also of significance to the people of Fiapre because the ability of the University to attract and retain personnel will help to assure them of accessible and quality tertiary education as well as job prospects in the community and the district as a whole. Professionally and academically, the study will contribute to knowledge and practice in management; especially worker motivation in organizations. It would also benefit educational managers at all levels in agrarian settings in the country in their staff motivation efforts.

Field research was guided by the following research questions:

1) What are the factors motivating staff at CUCG?

2) What motivating factors are available in the community as an agrarian area?

3) How can worker motivation be improved at CUCG?

\section{Study Methodology}

A cross-sectional design was used for the study. The target population for the study consisted of the management and staff of Catholic University College of Ghana, Fiapre. The total numerical strength of this population was 116 as at the time of the study. With regards to sample size, 80 out of the 116 were purposely selected for the study. Table 1 provides details about the categories and numerical figures of the staff at CUCG who were involved in the study.
Table 1.

Sample distribution.

\begin{tabular}{ccc}
\hline Category & Population & Sample \\
\hline Senior members (non-teaching) & 16 & 12 \\
Senior members (teaching) & 40 & 31 \\
Senior staff & 9 & 5 \\
Junior staff & 51 & 32 \\
Total & 116 & 80 \\
\hline
\end{tabular}

Source: field data 2010.

In this research, the questionnaire (both structured and semi-structured) was used as instrument to collect data. This questionnaire was adapted from a previous study done on a private university in Accra, Ghana. The questions were in three sections, namely, personal details of respondents, factors influencing respondents' motivation and lastly, how motivation of workers can be improved in the University. The questionnaire was personally administered to four (4) categories of staffs at CUCG. For some of the junior staff, some items needed to be explained to them in the local dialect.

The questionnaire items were pilot-tested at Pan-African University College. This population was chosen because Pan African University College is also a private university run by a church; and like CUCG, is also in an agrarian community. The questionnaire items which were irrelevant to our study were taken out, while others which were unclear were reframed and a few added. The questionnaire was further shown to some colleague researchers at the University of Education, Winneba (UEW) for scrutiny. They examined the questionnaire to ensure that they were guided by the research questions. To answer the research questions on the factors motivating staff at the Catholic University College of Ghana (CUCG), the following sample items were presented; to which respondents were guided by a six-pointed Likert scale (Absolutely Agree to Mostly Disagree):

- Good monthly pay is a motivator in my work at CUCG;

- A good allowance is a motivator in my work at CUCG;

- I am motivated by attractive fringe benefits which I enjoy from my employers;

- Personal satisfaction is a number one motivating factor for me;

- Achieving challenging tasks or goals motivate me;

- Study leave with pay is a good motivator in my work;

- Salary advance and loan support is a motivator in my work.

The psychometric property of the questionnaire in the initial study done in the private university in Accra was 0.96 . When it was later pilot-tested in our study, it was 0.91.

\section{Data Collection and Analysis}

A letter of introduction was administered earlier to the CUCG administration to solicit their cooperation regarding the study. Each in the sampled population was given a consent form to sign as indication of their willingness to participate in the study. The researchers assured all respondents of anonymity and confidentiality. However, anyone who felt uncomfortable and wished to discontinue in the process would be allowed to do so. Respondents were assured of confidentiality; these actions were taken in line with ethical considerations which need 
to be made in a research. All the staff who agreed to participate in the study, and who collected questionnaire returned them well completed.

Most of the questionnaires were pre-coded before administration to facilitate easy tabulation and analysis. Open-ended questionnaire were coded after the data collection exercise. Responses were cross-checked on the field as a quality check on the data. Coded data on responses were fed into the computer-based programme, SPSS for analysis. The programme generated figures, frequencies, percentages and tables to show the results of the data analysis. These descriptive statistics were then used as basis for discussing the key variables involved in the study. With regard to gender distribution, $81.2 \%$ i.e. 65 respondents were males and $18.8 \%$ i.e. 15 respondents were females.

From the analysis in Table 2, majority of the respondents (46.2\%) fell within the lowest monthly income group of GH4 120 - GH\$ 420, while the highest paid workers (2.5\%), earned between GH\$1921 and GHథ 2220 a month. (GHథ 1.60 is equivalent to \$1) Income levels of respondents were relevant to the study since monetary reward is an important factor in analyzing worker motivation. It should be stated that 8 respondents did not answer this item of the instrument. This attitude of the respondents was not surprising since a number of workers in Ghana do not feel comfortable disclosing their monthly income to others.

\section{Factors Motivating CUCG Staff}

From Table 3, $76 \%$ of the respondents saw monthly pay as a motivation factor in their work; and this confirms Doyle's (1992) emphasis on money as a motivator of work. According to Doyle (1992), though money may not be the most important motivational factor in every job situation, it is certainly a necessary consideration in every employment relationship. Despite the role of money as a motivator (Dery, 2007), about $28 \%$ of the respondents thought otherwise. This position also confirms Fillipezak's (1994) belief that money is not always a motivator to some people under certain circumstances.

Table 4 suggests that majority of the respondents (65\%) generally agreed that good allowance was a motivator. However,

Table 2.

Demographic characteristic of respondents by monthly income levels.

\begin{tabular}{ccc}
\hline Income range $(\mathrm{GH})$ & Count & Percentage \\
\hline $120-420$ & 37 & 46.2 \\
$421-720$ & 13 & 16.2 \\
$721-1020$ & 15 & 18.8 \\
$1021-1320$ & 0 & - \\
$1321-1620$ & 2 & 2.5 \\
$1621-1920$ & 2 & 2.5 \\
$1921-2220$ & 3 & 3.8 \\
No response & 8 & 10 \\
Total & 80 & 100 \\
\hline
\end{tabular}

Source: field data 2010 .
Table 3.

Good monthly pay as motivation among respondents.

\begin{tabular}{ccc}
\hline Good monthly pay as motivation & Count & Percentage \\
\hline Absolutely agree & 12 & 15 \\
Mostly agree & 23 & 28.8 \\
Somewhat agree & 11 & 13.7 \\
Agree & 15 & 18.7 \\
Absolutely disagree & 9 & 11.3 \\
Mostly disagree & 10 & 12.5 \\
Total & 80 & 100 \\
\hline
\end{tabular}

Source: field data 2010.

Table 4.

Attractive fringe benefits.

\begin{tabular}{ccc}
\hline Attractive fringe benefit & Count & Percentage \\
\hline Absolutely agree & 4 & 5.0 \\
Mostly agree & 12 & 15.0 \\
Somewhat agree & 16 & 20.0 \\
Agree & 10 & 12.5 \\
Mostly disagree & 8 & 10.0 \\
Absolutely disagree & 30 & 37.5 \\
Total & 80 & 100 \\
\hline
\end{tabular}

Source: field data 2010.

the degrees of acceptance varied from absolutely agree (10\%) to agree (15\%). Also, about $35 \%$ of the participants did not see good allowance as motivating. This group also varied in the degree to which they disagreed. Twenty-one percent of the respondents absolutely disagreed while about $14 \%$ of them mostly disagreed. This could be attributed to the fact that not every worker at the University has access to allowances. Even for those entitled to allowances, some were conditional, namely, vehicle or car maintenance allowance, book and research allowance, accommodation allowance, among others could be given, not to all, but rather certain categories of staff. This posture of the respondents (35\%) confirmed the assertion of Mullins cited in Armstrong (2001) that motivation is also intentional in the sense that it is under the control of the individual.

The study discovered that about $53 \%$ of the respondents were motivated by attractive fringe benefits as indicated on Table $\mathbf{5}$. This is distributed as absolutely agree (5\%) mostly agree (15\%) somewhat agree (20\%) and agree (13\%). This revelation by the respondents reflects the number of workers that receive fringe benefits from the University. Those employees who enjoy fringe benefits indicated that these benefits go a long way to support their monthly budget. It was also found that some participants (47\%) were not influenced by fringe benefits.

From Table 6, the number one motivator for most participants was personal satisfaction (90\%) but varied in the extent to which the satisfaction was drawn as showed on Table 6. The 
Table 5.

Personal satisfaction as a motivation factor.

\begin{tabular}{ccc}
\hline Personal satisfaction as motivation factor & Count & Percentage \\
\hline Absolutely agree & 29 & 36.2 \\
Mostly agree & 16 & 20.0 \\
Somewhat agree & 10 & 12.5 \\
Agree & 18 & 22.5 \\
Absolutely agree & 4 & 5.0 \\
Mostly agree & 3 & 3.8 \\
Total & 80 & 100 \\
\hline
\end{tabular}

Source: field data 2010 .

Table 6.

Achieving challenging tasks or goals.

\begin{tabular}{ccc}
\hline Achieving challenging tasks & Count & Percentage \\
\hline Absolutely agree & 23 & 28.8 \\
Mostly agree & 27 & 33.8 \\
Somewhat agree & 14 & 17.5 \\
Agree & 10 & 12.5 \\
Absolutely disagree & 2 & 2.5 \\
Mostly agree & 4 & 5.0 \\
Total & 80 & 100 \\
\hline
\end{tabular}

Source: field data 2010.

ability to assist students to satisfy their quest for knowledge is gratifying. In fact, most of the workers at the University, particularly lecturers and management staff who are passionate about quality education indicated that they derived personal satisfaction through offering services to the University as they received positive comments from some outfits where students did their Attachment or National Service.

Table 7 shows that 74 participants representing 93\% generally believe that achieving challenging tasks motivated them. This percentage is distributed according to the level of agreements. For example, $29 \%$ of the respondents absolutely agreed; $34 \%$ mostly agreed; $18 \%$ somewhat agreed and about $13 \%$ of the participants simply agreed to the statement. According to Maslow's needs hierarchy, achieving challenging task is on the self-actualization needs of man, and is pursued after having satisfied his basic physiological, safety, esteem and social needs (Maslow, 1954). The University provides opportunities for workers to strive for self-actualization by challenging lecturers in particular to help the University achieve its vision through the mission statement.

From Table 8, sixty-five (65) respondents, representing about $81 \%$ of participants agreed to good recognition as a motivational factor. However, $18 \%$ of them did not agree that good recognition motivated people to increase output or be more committed to work. According to Maslow's hierarchy, external esteem needs include high status, recognition, reputation, attention, or respect from among others. Therefore, a person will
Table 7.

Achieving challenging tasks or goals.

\begin{tabular}{ccc}
\hline Achieving challenging tasks & Count & Percentage \\
\hline Absolutely agree & 23 & 28.8 \\
Mostly agree & 27 & 33.8 \\
Somewhat agree & 14 & 17.5 \\
Agree & 10 & 12.5 \\
Absolutely disagree & 2 & 2.5 \\
Mostly agree & 4 & 5.0 \\
Total & 80 & 100 \\
\hline
\end{tabular}

Source: field data 2010.

Table 8.

Good recognition as a motivational factor.

\begin{tabular}{ccc}
\hline Good recognition as motivator & Count & Percentage \\
\hline Absolutely agree & 9 & 11.2 \\
Mostly agree & 27 & 33.8 \\
Somewhat agree & 15 & 18.8 \\
Agree & 14 & 17.5 \\
Absolutely disagree & 6 & 7.5 \\
Mostly disagree & 9 & 11.2 \\
Total & 80 & 100 \\
\hline
\end{tabular}

Source: field data 2010.

seek recognition after satisfying the physiological and safety needs.

From Table 9, it is evident that most of the respondents were motivated by human relationships among the staff. Out of the 80 respondents, 77 representing 96\% indicated that friendly relations among staff kept them working hard. They agreed that it was gratifying to see a "superior" officer being the first to greet a "subordinate" at work, which is not necessarily the case at other organizations. These seemingly unique relationships among the staff of the Catholic University College of Ghana seemed to have propelled most respondents to work harder with less or no supervision. The responses of the participants are in conformity with McClelland's Achievement Affiliation-power needs theory (cited in Cole, 1996) that people have the desire to establish and maintain close friendly relations with others; and interestingly, the University has measures in place to satisfy this human need at daily prayer and at official ceremonies. (Vice Chancellor's Annual Report, 2009)

The information displayed on Table 10 shows that out of 80 respondents, 62 (78\%) of them agreed to career development as a motivator. The University provides these opportunities by way of encouraging and supporting all competent and qualified staff to pursue higher degrees in their fields. Alderfer (1972) in his Existence, Relatedness and Growth (ERG) theory of motivation suggests that a personal growth is an intrinsic desire by employees as a means of boosting their status recognition. One direct means to attaining personal growth is career development. 
Table 9.

Friendly relation among staff as a source of motivation.

\begin{tabular}{ccc}
\hline Friendly relation among staff & Count & Percentage \\
\hline Absolutely agree & 25 & 31.3 \\
Mostly agree & 21 & 26.2 \\
Somewhat agree & 16 & 20.0 \\
Agree & 15 & 18.8 \\
Absolutely disagree & 2 & 2.5 \\
Mostly disagree & 1 & 1.2 \\
Total & 80 & 100 \\
\hline
\end{tabular}

Source: field data 2010.

Table 10.

Career development as a motivator.

\begin{tabular}{ccc}
\hline Career development as motivator & Count & Percentage \\
\hline Absolutely agree & 14 & 17.5 \\
Mostly agree & 21 & 26.2 \\
Somewhat agree & 15 & 18.8 \\
Agree & 12 & 15.0 \\
Absolutely disagree & 13 & 16.3 \\
Mostly disagree & 5 & 6.2 \\
Total & 80 & 100 \\
\hline
\end{tabular}

Source: field data 2010 .

Even though the levels of agreements by respondents vary as evidenced on the table above, a total of $78 \%$ of the respondents generally agreed to career development as a factor that motivates them, although they varied in the level of agreements. However, $22 \%$ of the respondents believed that they lacked career development prospects as indicated on the table.

From Table 11 respondents (57\%) essentially agreed that loan support and salary advance was a motivational factor at work in the University. It should however, be stated that this percentage represents variant degrees of agreements and ranges from absolutely agree to agree as seen on the table. For the rest of the respondents (43\%) being given loan support and salary advance or not did not seem to directly affect their work output.

Table 12 shows that 48 respondents representing 60\% disagreed with the proposal that workers were motivated by support from the University to upgrade themselves. According to this group, the policy on study leave with pay in itself was good. However, there were difficulties that prevented the University from implementing it. Also, the conditions attached to this facility was said to discourage workers. For example, it was a policy that one had to work in the University for at least three consecutive years to qualify for his facility. The study also revealed that out of the 80 respondents, thirty-two (32) participants representing about $40 \%$ believed that the opportunity to obtain study leave with pay while pursuing an academic programme was a motivational factor.

From Table 13, 50\% of the respondents said that low cost
Table 11.

Loan support \& salary advance as motivator.

\begin{tabular}{ccc}
\hline Loan support and salary advance & Count & Percentage \\
\hline Absolutely agree & 5 & 6.2 \\
Mostly agree & 15 & 18.7 \\
Somewhat agree & 11 & 13.7 \\
Agree & 15 & 18.8 \\
Absolutely disagree & 27 & 33.8 \\
Mostly disagree & 7 & 8.8 \\
Total & 80 & 100 \\
\hline
\end{tabular}

Source: field data 2010.

Table 12.

Study leave with pay as a motivational factor.

\begin{tabular}{ccc}
\hline Study leave with pay as motivator & Count & Percentage \\
\hline Absolutely agree & 10 & 12.5 \\
Mostly agree & 7 & 8.7 \\
Somewhat agree & 7 & 8.8 \\
Agree & 8 & 10.0 \\
Absolutely disagree & 40 & 50.0 \\
Mostly disagree & 9 & 10.0 \\
Total & 80 & 100 \\
\hline
\end{tabular}

Source: field data 2010.

Table 13.

Motivational factors in the Sunyani-West district.

\begin{tabular}{ccc}
\hline Factor & Count & Percentage \\
\hline Low food prices & 40 & 50.0 \\
Cond rent & 25 & 31.2 \\
Availability of educational facilities & 5 & 6.3 \\
Total & 10 & 12.5 \\
& 80 & 100
\end{tabular}

Source: field data 2010.

of foodstuff due to proximity to the farm gates encouraged them to stay and work in the district. Thirty-one percent (31\%) of them were motivated by low rent because participants indicated that it was cheaper to rent accommodation in this area than in the cities of Ghana. Furthermore, the Sunyani West District is blessed with many schools. About $13 \%$ of the respondents indicated that they were motivated by the availability of educational facilities, where their children could have access to quality education. This is because of the presence of secondary/technical schools as well as a public University (Faculty of Forestry Resources Technology of the Kwame Nkrumah University of Science and Technology) and a private University 
(Catholic University College of Ghana) in the district.

\section{How Can Worker Motivation Be Improved in the CUCG?}

The study discovered that the basic salaries of the workers were being reviewed upwards each financial year of the University, taking into account salaries of other institutions in Ghana. Management also disclosed that the current salaries of employees in the University were generally higher than those of the public universities. Indeed, there had been consistent increase in basic salaries in the CUCG since its establishment. On allowances, management revealed that inducement allowances had been increased from $30 \%$ to $150 \%$ of basic salary, which may still be reviewed upwards depending on the market trend and the financial ability of the University. This confirmed the results of the respondents on good allowances where $65 \%$ of them recognized good allowances as a source of motivation for output (see Table 4).

The management was asked to indicate how staff association was encouraged as motivation to employees. It was discovered that management did not in any way hinder the formation and operation of staff associations. To enhance the activities of staff associations, management had always granted members free time to attend meetings and programmes of associations; stemming from management's belief that staff associations can help in the smooth running of the University since their leaders could be a link between management and workers. To demonstrate in concrete terms management support for staff associations, a welfare committee had been formed and monies were being contributed to improve staff welfare.

Regarding work environment, it was found that management was much interested in providing an attractive working environment to motivate workers. There is greater emphasis on cleanliness and maintenance. The researchers observed cleaners on a regular basis busily doing their work; and this added to the welcoming atmosphere of the University. For career development, it was revealed that all staff were encouraged by management to obtain higher qualifications. The conditions of service had created opportunities for staff development where a staff could have study leave with pay up to a three year period.

The last factor to consider as effort made by management in motivating staff was fringe benefits. Respondents mentioned the following as some of the fringe benefits enjoyed by members of staff: $50 \%$ subsidy for rent, subsidy for transportation, Christmas gift, payment of medical bills, and $25 \%$ of basic pay contribution towards staff retirement benefits.

\section{Discussion}

There is no doubt that education, especially at the tertiary level, is the bedrock of development and progress of any nation. For a third world nation like Ghana, in a globalized world, this need is even greater. Those who have the capacity and/or the mandate to run institutions of higher learning need to keep some key points in mind. First of all, it is quite tempting to wish to set up a university in one of the cities, considering that these are where the bulk of the quality human resources reside, or would like to be.

Yet, fact is that Ghana's cities are already choked, and this study has shown that it is not necessary for owners or strategists to set up their universities in those cities; agrarian communities could equally serve as excellent locations for very successful institutions of higher learning. The study has shown that if certain important motivating factors are paid attention to, workers would be attracted to come, and be happy to remain and work for greater output.

The study has shown that even though money is a good motivator for greater work output, there are a number of other factors that motivate workers to put up their best. A good lesson for leaders of institutions, including educational settings is that they should endeavor to create or improve upon conditions which will allow workers to aim at achieving challenging tasks or goals, since these could also motivate some staff, as shown in this study.

Especially for those educational leaders who wish to be innovative in setting up or running universities outside the cities, they would need to consider helping to create environments where staff would be given due recognition, an aspect which is often missing in a number of large organizations in Ghana. Closely related to this is another lesson that leaders should derive - that friendly and healthy relations at the university could serve as sufficient incentive to attract and to keep a very important human resource at post.

Furthermore, it is important that rather than see it as too expensive, leaders in higher educational institutions should do well to provide sufficient avenues for their staff in terms of career development as well as promotion prospects. This study has shown that it takes a lot of things to get good workers attracted to an organization, and sometimes that organization could be far away from the city, and yet would attract excellent staff, providing excellent job output.

\section{Conclusion}

This study will conclude by making some recommendations for future action informed by the findings of the study. From the findings of this study, and in order to further improve worker motivation and job output at CUCG, the following recommendations were made to the management, the board of trustees as well as owners and policy makers of the University.

Firstly, it is being recommended to the management of the Catholic University College of Ghana, Fiapre and the Board of Trustees that a joint Negotiating Committee be set up at the appropriate level of authority to formally appraise and review the existing conditions of service for the staff. Disparities in fringe benefits between junior staff and professional staff should be properly explained to the junior staff so as to minimize the general feeling of dissatisfaction among them. Staff awards and performance based rewards should be instituted to recognize hard working employees in the University.

Secondly, the university could liaise with other universities that offer graduate programmes to accept young staff from CUCG for further professional development. This will improve and further facilitate the upgrading of staff to enhance quality education delivery. To enhance this, the University should consider arranging for possible sponsorships and grants to support staff for further studies.

Finally, it is being recommended to the policy makers and owners of the University to increase their education campaign to encourage present and prospective staff about the many benefits of staying and working in an agrarian community such as CUCG as well as helping to reduce the rural-urban drift among Ghanaians in general. 


\section{A. AFFUL-BRONI, S. NANYELE}

\section{REFERENCES}

Afful-Broni, A. (2004). Theory and practice of educational leadership in Ghana. Accra: TYPE Press.

Alderfer, C. (1972). Existence, relatedness and growth: Human needs in organizational settings. New York: Free Press.

Armstrong, M (2001). A handbook of human resources management practices (8th ed.). London: Book Power/ELST.

Cohen, M., \& Marrison, J. (2003). Designing a qualitative study. Newsbury Park, CA: Sage Publications.

Cole, G. A. (1996). Management theory and practice (5th ed.). London: Book Power/ELST.

Cole, G. A. (2002). Personnel and human resource management (5th ed.). London: Book Power/ELST.

Creswell, J. W. (2005). Educational research planning conducting and evaluating quantitative and qualitative research (2nd ed.). Upper Saddle River, NJ: Merrill Prentice.

Dery, S. (2007). Leadership and management within schools in Ghana: Unique challenges compared to Wales. Wales: NEWI.
Doyle, K. O. (1992). Introduction: Money and the behavioural sciences. American Behavioural Scientist, 35, 641-657.

Fillipezak, B. (1994). Can’t buy me love. Training, 33, 29-34.

Maslow, A. (1954). Motivation and personality. New York: Harper and Row

Miskell, J. R., \& Miskell, V. (1999). Motivation at work. New York: Irwin Inc.

Robbins, S. P., \& Laughton, N. (2001). Organizational behavior: Concepts, controversies and application (2nd ed.). Toronto: Prentice Hall.

Sefa, D. A. (2007). Employee motivation and productivity in three organizations in Accra: Peace FM, pipes and plastics and poly products. Cape Coast: University of Cape Coast.

Thaw, D. (2002). Ideas for change: People in organizations. London: Olive Publications.

Valogo, M. K. (2007). Motivation and retention of graduate teachers: A case study of senior secondary schools in Bolgatanga municipality. Cape Coast: University of Cape Coast.

Vice Chancellor's Annual Report (2009). Fiapre: Catholic University College of Ghana. 